\title{
Forecasting Method Selection Based on Operational Performance
}

\author{
Yavuz Acar* \\ Boğaziçi University
}

\begin{abstract}
This paper evaluates alternative forecasting methods based on operational performance in a global specialty chemicals supply chain. The forecasting methods evaluated in this study are simple exponential smoothing, exponential smoothing with additive trend, and exponential smoothing with damped additive trend. These methods are evaluated at various target customer service levels based on the operational performance of the supply chain. The operational performance measures used in this study are total supply chain costs, broken down into inventory, production and shipment costs, and also four different measures of customer service level. The company's supply chain operations are simulated and the results are analyzed using the Analysis of Variance (ANOVA) procedure followed by the Tukey's means test. The effects of using the competing forecasting methods on each of the performance measures are evaluated and discussed individually. Our results underscore the importance of incorporating all relevant costs and customer service measures into the forecasting method selection process, which is only possible with a thorough understanding of the supply chain dynamics. In the environment we modeled, exponential smoothing with damped additive trend was by far the best in terms of both resulting supply chain costs and customer service levels, followed by simple exponential smoothing and exponential smoothing with additive trend.
\end{abstract}

Keywords: supply chain, demand forecasting, simulation, exponential smoothing,

\section{Operasyonel Performansa Dayalı Talep Tahmin Yöntemi Seçimi}

\section{Özet}

Bu makalede özel kimyasallar üreten bir firmanın küresel tedarik zincirinde farklı talep tahmin yöntemlerinin operasyonel performans üzerindeki etkileri değerlendirilmektedir. Çalışmaya tek üssel düzeltme yöntemi, doğrusal trendli üssel düzeltme yöntemi ve sönümlü trendli üssel düzeltme yöntemi dahil edilmiştir. $\mathrm{Bu}$ yöntemlerin tedarik zinciri performansı üzerindeki etkisi çeşitli hedef müşteri hizmet seviyelerinde değerlendirilmiştir. Tedarik zinciri operasyonel performans ölçütleri olarak envanter, üretim ve nakliye maliyetinden oluşan toplam tedarik zinciri maliyeti ve bunun yanında dört farklı müşteri hizmet ölçütü kullanılmıştır. Firmanın tedarik zinciri operasyonlarının

* Yavuz Acar is an Assistant Professor in the Department of Management at Boğaziçi University, 34342, Bebek, Istanbul, Turkey. E-mail: yavuz.acar@boun.edu.tr 
simülasyonu yapılmıştır ve elde edilen sonuçlar varyans analizi (ANOVA) ve Tukey’nin ortalama testi kullanılarak analiz edilmiştir. Kullanılan talep tahmin yöntemlerinin her bir performans ölçütü üzerindeki etkisi ayrı ayrı değerlendirilmiş ve tartışılmıştır. Elde edilen sonuçlar, talep tahmin yöntemi seçiminde ilgili tüm maliyet ve müşteri hizmet ölçütlerinin hesaba katılmasının önemini vurgulamaktadır. Bu da tedarik zinciri dinamiklerinin iyi anlaşılmış olmasını gerektirmektedir. Mevcut tedarik zinciri ortamında sönümlü trendli üssel düzeltme yöntemi, hem maliyet hem de servis ölçütlerine göre en iyi sonucu vermiştir. Sönümlü trendli üssel düzeltme yöntemini sırasılyla tek üssel düzeltme yöntemi ve doğrusal trendli üssel düzeltme yöntemi izlemiştir.

Anahtar kelimeler: tedarik zinciri, talep tahmini, simülasyon, üssel düzeltim, özel kimyasallar, tahmin hata ölçütleri.

complicating factor in supply chain decision-making is the presence of uncer-
tainty. Sources of uncertainty include demand, supply, lead times, and exchange
rate fluctuations in international scenarios. On the demand side, the negative effect of uncertainty is well documented (Lee and Billington, 1995; Lee et al., 1997; Vidal and Goetschalckx, 2000; Chen et al., 2000; Qi et.al., 2004; Acar, 2010). However, forecasting methods that can potentially alleviate the negative impact of demand uncertainty and improve operational performance have not been adequately studied on the basis of operational benefits.

The supply chain studied in this research is that of a major global manufacturer of fuel additives and lubricants, typically classified as specialty chemicals. The company recently launched a cost-reduction initiative which was principally stimulated by the considerable cost of holding high levels of inventories at manufacturing sites. To this company, it was of utmost importance to maintain acceptable customer service levels while reducing inventories. This research was launched as part of this initiative. We modeled the supply chain using forecasted demand data and both optimization and simulation techniques. The optimization, a mixed integer program, develops production, inventory, and transportation plans that minimize total supply chain costs, given the demand forecasts. A simulation model then executes these plans in the presence of demand, lead-time and supply uncertainties.

The forecasting methods evaluated in this research are: 1) Simple Exponential Smoothing, 2) Holt's Exponential Smoothing with Additive Trend (Holt, 2004), and 3) Exponential Smoothing with Damped Additive Trend (Gardner and McKenzie, 1985). Comparison of the performances of the alternative forecasting methods involved simulating the supply chain under conditions of actual demand, and under lead-time and supply uncertainties. The resulting supply chain costs and demand fulfillment capabilities were observed.

Results of a preliminary analysis using supply chain costs and customer service as performance criteria are published in Acar and Gardner (2012). Their analysis involved constructing tradeoff curves between the total supply chain costs and two measures of 
customer service: weighted tardiness and number of backorders. Figure 1 gives a tradeoff curve for total supply chain costs vs. numbers of backorders. The plotted symbols on each curve represent the five levels of safety stock, and the corresponding costs and service measures are averages of the replications at each level. Exponential Smoothing with Damped Additive Trend (DA-N) gives the best tradeoffs, that is the lowest cost for any customer service level, followed by Simple Exponential Smoothing (N-N) and Holt's Exponential Smoothing with Additive Trend (A-N).

\section{Figure 1}

Tradeoffs between Total Supply Chain Cost and Number of Backorders during the Last Year of Operations (Acar and Gardner, 2012).

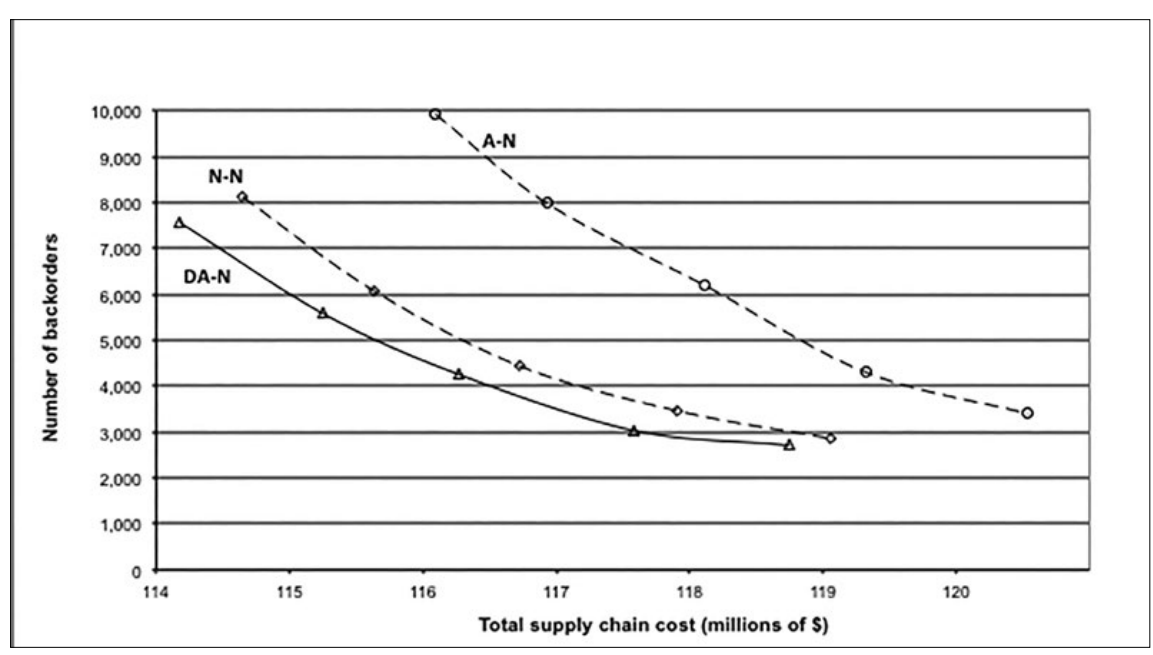

In this current paper, supply chain costs are broken down into inventory, production and shipment costs; demand fulfillment capabilities are broken down into weighted tardiness (product of number of days late and quantity late), weekly backordered quantities, number of late orders, and percent of late orders (these will be referred to as customer service "measures" in the remainder of the paper). Extended analysis and discussion of the results are presented through ANOVA and Turkey's means test (Tukey, 1949) based on each supply chain cost component and service level measure.

In the remainder of this paper, we provide a literature review, describe our research methodology and outline our experimental design, present our results and discussion based on each performance measure, and finally present our conclusions.

\section{Literature Review}

A number of studies concern the selection of forecasting methods on the basis of operational benefits.

Adshead and Price (1987) developed a simulation model of an actual make-to-stock shop and conducted a series of analyses in which the demand forecasting method was 
varied. Real demand for individual products was used to drive the simulation experiment. The authors developed a cost function that includes inventory carrying costs, stock-out costs and overtime cost to compare the performance of the forecasting methods. They experimented with four discrete parameters in the simple exponential smoothing, the double smoothing version of the Holt's additive trend method, and Brown's quadratic exponential smoothing methods. To obtain discrete values of model parameters that provide equivalent performance across the methods, they used Brown's equivalence criterion. Because of the difficulty involved in quantifying stock-out costs, they experimented with three levels of stock-out costs $(4,9$, and 19 times the stock holding costs). As their results show, the simple exponential smoothing method in general performed better than the other methods.

Gardner (1990) compared random walk, simple exponential smoothing, exponential smoothing with additive trend and exponential smoothing with damped additive trend methods in a U.S. Navy distribution system comprising more than 50,000 inventory items. Because of the large number of inventory items, a single method was selected for forecasting all inventory items in the study. Delivery delay time and inventory investment were used as operational performance measures. A large-scale simulation model of the inventory system was developed to generate the trade-off curves used to evaluate alternative forecasting models. Smoothing constants of the competing models were chosen so as to yield minimum delay time, a key output of the simulation model. As trade-off analysis demonstrated, the damped additive trend model was superior to the other methods studied and was consequently implemented by management to reduce inventory investment by $\$ 30$ million (7\%).

Flores et al. (1993) compared the forecasting methods of simple exponential smoothing, Brown's one-parameter double exponential smoothing, adaptive exponential smoothing, and median as forecast in an electronic parts distribution system comprising 967 inventory items. Because of the large number of inventory items, these authors also employed the strategy of selecting one method to forecast all series. The costs associated with excess inventories and the cost of lost sales were used as performance measures. The selling price was varied to yield four levels of gross margin, and holding cost was varied at three levels, resulting in 12 runs for each inventory item. The different levels of selling price cause variations in the cost of lost sales, while the different levels of holding cost cause variations in the cost of over-forecasting. The authors consequently showed that, across the 12 runs, the total cost changes as the cost structure varies, while the measures of forecast accuracy do not vary. Surprisingly, the median-as-forecast method generated the lowest total cost when a $10 \%$ gross margin was used, simple exponential smoothing generated the lowest total costs when a $20 \%$ margin was used, and all four methods generated similar total costs when gross margins of $30 \%$ or $40 \%$ were used. This study was limited by the use of fixed smoothing parameter values in all exponential smoothing models compared. The authors did note that their results are valid within the boundaries of the study and that a broader study may result in different conclusions. Sensitivity to changes in inventory carrying cost was also analyzed in the study. 
Eaves and Kingsman (2004) compared five methods for forecasting operational performance in a supply chain comprising a Royal Air Force inventory of 11,203 spare parts. The methods were the original Croston's method, a modification of Croston's that Eaves and Kingsman had proposed in order to correct a bias discovered previously by Syntetos and Boylan (2001), the simple smoothing method, the 12-month moving average method, and the simple previous-year's average method. They identified a weakness associated with using traditional measures of accuracy in the presence of intermittent demand and developed an alternative measure based on implied stock holdings to which a monetary value can easily be applied. Using a backward-looking simulation that assumed a common service level of $100 \%$, they calculated the mean stock holdings implied by each forecasting method and optimized the smoothing parameters for minimizing stock holdings. As the results showed, the modified version of Croston's method performed generally better than all of the other methods and generated a savings of $13.6 \%$ when compared with the simple smoothing method.

More recently, Tiacci and Saetta (2009) compared two simple forecasting methods in a simulation study of a warehousing operation. The methods produced similar total costs, but the less accurate method gave better customer service. In another warehousing simulation, Sanders and Graman (2009) showed that bias in the forecasts was more important than average accuracy in determining warehousing and inventory costs. Using real data drawn from a distribution inventory, Syntetos et al. (2009) showed that marginal improvements in average accuracy led to much larger improvements in inventory costs.

Even though operational performance is the primary concern of management, in the literature to date, only a handful of researchers have examined it as the basis for forecasting method selection. To our knowledge, still to date, there is no published research about the evaluation/selection of forecasting methods which looks into the operational benefits in a global supply chain environment.

\section{Research Methodology}

\section{The Supply Chain Model}

We worked closely with the supply chain managers of a global specialty chemicals firm in the development of the supply chain model. The model includes four manufacturing plants in North and South America, Europe, and Asia. Ten principal components are produced in a push mode based on 6-month forecasts. Each customer order for end products is prepared after an order is received using a pull mode by blending the components according to the appropriate product recipe. This study focuses on the supply chain for the ten components for which forecasts are needed. A significant amount of stock transfers takes place among the manufacturing plants. The stock transfers are made in three principal modes of transportation: in bulk, in ISO containers using marine vessels, and in smaller quantities using trucks. Transportation modes have varying costs and lead times. 
The supply chain planning model uses optimization while simulation techniques are used to analyze the execution of these plans. Supply chain planning is performed at two (tactical) levels. The top level plan produces a monthly master production schedule and a stock transfer plan for the components over a 6month planning horizon. The lower level plan generates a weekly production schedule for the components on each machine at all plants over a 12-week planning horizon. Mixed Integer Programming (MIP) models are developed to generate these tactical plans. A simulation model then implements the daily execution of the weekly plans in the presence of demand, lead-time and supply uncertainties. At the end of each week, the simulator records various costs and customer service measures. Interested readers are referred to Acar et al. (2010) for further details of the supply chain model.

The company's supply chain specialists extracted data from their information system to be used in the development of the models. At this step, we worked closely with the supply chain specialists from the company to ensure data integrity. The following data were provided: Four years of demand history for the 10 components at the four manufacturing plants, production costs by machine by plant, transportation costs for each mode of transportation, import tariffs for the countries involved, production rates for the ten components by machine by plant, production capacities, transportation lead times among plants for each mode of transportation, rules for transportation mode assignment (ISO container vs. bulk) based on order quantity, and business rules concerning machine changeover requirements.

\section{Forecasting Methods}

The forecasting methods included in this study are simple exponential smoothing, exponential smoothing with additive trend, and smoothing with damped additive trend. Simple exponential smoothing is included due to its popularity in practice as well as in research. Exponential smoothing with additive trend, a method also widely used by practitioners, is included due to the prevalence of trend in the majority of the demand data we were provided. Damped additive trend (Gardner and McKenzie, 1985) is reported to perform well in previous research (Makridakis et al., 1982; Makridakis and Hibon, 2000), and avoids overshooting the data at long forecast horizons - which may be the case when the additive trend method is used. Methods including seasonality have not been included in this study because autocorrelations at seasonal lags were not significant for our demand data.

The forecasting method parameters are obtained as follows: Four years of demand data are separated into two sets. The first three years of demand data are used as the fit data set to fit the forecasting models and to estimate the smoothing parameters. Since visual inspection reveals that the time series patterns differ across plant-component combinations, model fitting is carried out separately, for each of the three exponential smoothing methods. The Mean Squared Error (MSE) measure is used as the basis for parameter optimization. The simple exponential smoothing method is initialized by setting the initial level equal to the monthly average of the first year's demand. For the remaining two methods including a trend term, the initial level and the initial trend are computed by regressing the first year's monthly demand on time. 


\section{Experimental Design}

Revealing the costs associated with achieving various customer service levels for the plant-components was an integral part of this study. Therefore, we varied safety stock levels of the plant-components to achieve five levels of customer service targets, defined as the percentage of demand fulfilled without any delay. The safety stock levels for various service levels are calculated via bootstrap simulation which involves simulating $\mathrm{m}$-step-ahead demand and avoids the assumption of normality of demand. Constructing the prediction interval for $\mathrm{m}$-step-ahead demand involves the following steps:

1. Simulate $\mathrm{m}$ values for forecast error, $\mathrm{e}_{\mathrm{t}}, \mathrm{t}=1,2, \ldots, \mathrm{m}$ from a normal distribution with mean 0 and standard deviation $\sigma$. Obtain $\sigma$ using the following formula

$$
\sigma=\sqrt{\frac{\text { Sum.of.Squared.Erros(SSE) }}{n-\text { number.of.smoothing.constat }}}
$$

where $\mathrm{n}=$ number of observations.

SSE is obtained by using a nonlinear optimization method. Forecast errors are assumed to be normally distributed in this procedure.

2. Generate $m$ values for $X_{t}, t=1,2, \ldots, m$, using one-step-ahead demand and smoothing equations, $e_{t}$ from Step 1 and smoothing parameters. Smoothing parameters are obtained by using a nonlinear optimization method. We used Excel Solver to minimize Mean Squared Errors (MSE) at this stage of this study.

Repeating the above steps $\mathrm{K}$ times yields a sample of $\mathrm{K}$ values of $\mathrm{y}_{\mathrm{m}}(\mathrm{m}$-stepahead demand), which is used to construct the prediction intervals. Then, the prediction intervals are used to determine the required safety stocks for a given service level.

Example: If the simple exponential smoothing method is adopted, then 3-step-ahead demand distribution can be simulated as follows:

Step 1: Simulate 3 values for $\mathrm{e}_{\mathrm{t}}, \mathrm{t}=1,2,3$, from a normal distribution with mean 0 and standard deviation $\sigma$.

Step 2:

$\mathrm{t}=1, X_{1}=S_{0}+e_{1}$ and $S_{1}=\alpha X_{1}+(1-\alpha) S_{0}$

( $e_{1}$ is generated in step $1, \alpha$ is obtained by minimizing MSE, $S_{0}$ is the initial level)

$\mathrm{t}=2, X_{2}=S_{1}+e_{2}$ and $S_{2}=\alpha X_{2}+(1-\alpha) S_{1}\left(e_{2}\right.$ is generated in step 1$)$

$\mathrm{t}=3, X_{3}=S_{2}+e_{3}\left(e_{3}\right.$ is generated in step 1$)$ 
Repeating steps 1 and $2 \mathrm{~K}$ times can obtain a sample of $\mathrm{K}$ values of $\mathrm{X}_{3}$ (3-step ahead demand). This sample can be used to calculate required safety stock levels.

The experimental factors are summarized in Table 1. Implementation of the three forecasting methods and the five levels of customer service resulted in 15 experimental combinations. Twenty simulation replications are made for each of the experimental combinations resulting in 300 simulation runs. Statistics on cost and customer service level measures are collected during the twelve month rolling horizon simulation of the supply chain operations. The results are analyzed by using the ANOVA procedure and Tukey's means tests for each of the performance measures.

Table 1

\section{Experimental Factors in Forecasting Method Comparison based on Supply Chain} Performance

\begin{tabular}{l|l}
\hline \multirow{2}{*}{ Experimental Factors } & Factor Levels \\
\cline { 2 - 2 } Forecasting Methods & $\begin{array}{l}\text { Simple Exponential Smoothing (N-N) } \\
\text { Exponential Smoothing with Additive Trend (A-N) } \\
\text { Exponential Smoothing with Damped Additive Trend (DA-N) }\end{array}$ \\
\cline { 2 - 2 } Customer Service Level & $69.14 \%$ (corresponding to 0.5 standard deviation) \\
& $84.13 \%$ (corresponding to 1 standard deviations) \\
& $93.33 \%$ (corresponding to 1.5 standard deviations) \\
& $97.72 \%$ (corresponding to 2 standard deviations) \\
& $99.38 \%$ (corresponding to 2.5 standard deviations) \\
\hline
\end{tabular}

\section{Performance Measures Used in This Study}

The following operational measures are used as performance indicators in this study:

1) Service Level Measures:

- Weighted Tardiness (Ton x Day): When an order is late, it is backordered. During the simulation, backorders are given higher priority and they are met as soon as inventory is available. Weighted tardiness for each backorder is calculated by multiplying the number of days it is backordered by the backorder quantity. When there is a partial shipment of an order, remaining order quantity is backordered and used in weighted tardiness calculation. This measure takes both quantity and time into account. During the simulation, weekly weighted tardiness is calculated for each component.

- Number of Orders Late: During the simulation, the number of late orders is recorded weekly for each component.

- Weekly Backordered Quantities (Tons): The quantity of backorders is recorded at the end of every week during the simulation.

- Percent of Orders Late: The percent of orders late is obtained by dividing the number of orders late by the total number of orders received. 


\section{2) Cost Measures:}

- Total Inventory Cost: Inventory carrying cost for inventory kept in the plants and for inventory in transit is calculated during the simulation. Weekly inventory levels at the plants are recorded at the end of each week and used in the calculation of the inventory carrying costs. Monthly per unit inventory carrying costs are assumed to be $1 \%$ of the production costs.

- Total Shipment Cost: Component shipment costs are recorded at the end of the month during a simulation run. The cost depends on the quantity shipped as well as the transportation mode (ISO vs bulk container). If the shipment quantity exceeds 300 metric tons, shipment by bulk container is scheduled and the cost associated with bulk shipment is charged. Conversely, if the shipment quantity is less than 300 metric tons, shipment by ISO container is scheduled and charged.

- Total Production Cost: Throughout a simulation run, the production cost of each component is recorded at each plant whenever production takes place.

- Total Supply Chain Cost: Sum of inventory, production and shipment costs.

\section{Results}

\section{ANOVA and Tukey's Means Test Results: Customer Service Measures}

ANOVA results presented in Tables 2-5 show that both the forecast method used and the safety stock setting have a significant impact on all customer service measures. The interaction effect, as well as the main effects, are significant at 1\% level. Table 6 summarizes the results of Tukey's means test. Figures 2-5 show the effect of the interaction between the forecasting method used and safety stock settings.

The results in Figures 2-5 indicate that the difference among the three forecasting methods in terms of customer service performance diminishes as the safety stock levels are increased to provide higher customer service levels. For example, the difference in weighted tardiness between the DA-N versus the A-N methods is 75,640.02 ton-days when the safety stock is set to provide a $69.1 \%$ customer service level. The difference goes down to $11,356.41$ ton-days when the safety stock is set to provide a $99.4 \%$ customer service level (see Figure 3). Similarly, the difference in weighted tardiness between the N-N versus A-N methods is as high as 63,448.08 ton-days when the safety stock is set to provide a $69.1 \%$ customer service level. The difference reduces to $4,319.66$ ton-days when the safety stock is increased to provide a $99.4 \%$ customer service level. The interaction effect between the safety stock and the forecasting method used is quite remarkable based on these results.

Tables 2 to 6 show that the main effects of the forecasting method used on customer service measures. The choice of forecasting method significantly affects customer service. The exponential smoothing method with damped additive trend (DA-N) delivers statistically significantly better customer service results than the other two forecasting methods, and this is true for all safety stock settings. The simple exponential smoothing 
(N-N) method delivers the second best performance in terms of all customer service measures, and is statistically significantly better than the exponential smoothing with additive trend (A-N) method (see Table 6).

Table 2

ANOVA Results for the Weighted Tardiness Measure

\begin{tabular}{llll}
\hline Weighted Tardiness (ton-days) & $\mathrm{R}^{2}: 0.936$ & & \\
\hline Source & $\mathrm{DF}$ & $\mathrm{F}$ & $\mathrm{Pr}$ \\
\hline Model & 14 & 314.597 & $<.0001$ \\
\hline Forecasting_Method & 2 & 291.635 & $<.0001$ \\
\hline Safety_Stock & 4 & 890.614 & $<.0001$ \\
\hline Forecasting_Method* Safety_Stock & 8 & 32.329 & $<.0001$ \\
\hline
\end{tabular}

Table 3

ANOVA Results for the Number of Late Orders

\begin{tabular}{llll}
\hline Number of Late Orders & \multicolumn{4}{l}{$\mathrm{R}^{2}: 0.962$} & & \\
\hline Source & $\mathrm{DF}$ & $\mathrm{F}$ & $\mathrm{Pr}$ \\
\hline Model & 14 & 534.472 & $<.0001$ \\
\hline Forecasting_Method & 2 & 438.572 & $<.0001$ \\
\hline Safety_Stock & 4 & 1617.252 & $<.0001$ \\
\hline Forecasting_Method * Safety_Stock & 8 & 17.057 & $<.0001$ \\
\hline
\end{tabular}

Table 4

ANOVA Results for Weekly Backorder Quantities

\begin{tabular}{llll}
\hline Weekly Backorder Quantity & R $: 0.941$ & & \\
\hline Source & $\mathrm{DF}$ & $\mathrm{F}$ & $\mathrm{Pr}$ \\
\hline Model & 14 & 339.347 & $<.0001$ \\
\hline Forecasting_Method & 2 & 111.341 & $<.0001$ \\
\hline Safety_Stock & 4 & 1126.723 & $<.0001$ \\
\hline Forecasting_Method * Safety_Stock & 8 & 2.66 & .008 \\
\hline
\end{tabular}


As expected, all customer service measures improve as the safety stock levels are increased. For example, the number of late orders obtained under the DA-N method gradually decreases from 7,590 to 2,712 as the safety stock is varied from a customer service level of $69.1 \%$ to a customer service level of $99.4 \%$ (see Figure 2).

Table 5

ANOVA Results for the Percent of Orders Late

\begin{tabular}{|c|c|c|c|}
\hline Number of Late Orders & \multicolumn{3}{|c|}{$\mathrm{R}^{2}: 0.962$} \\
\hline Source & $\mathrm{DF}$ & $\mathrm{F}$ & $\operatorname{Pr}$ \\
\hline Model & 14 & 534.472 & $<.0001$ \\
\hline Forecasting_Method & 2 & 438.572 & $<.0001$ \\
\hline Safety_Stock & 4 & 1617.252 & $<.0001$ \\
\hline Forecasting_Method $*$ Safety_Stock & 8 & 17.057 & $<.0001$ \\
\hline
\end{tabular}

Table 6

Tukey's Means Test Results for the Customer Service Measures $(\mathbf{n}=100)$

\begin{tabular}{|c|c|c|c|c|c|}
\hline \multicolumn{3}{|c|}{ Weighted Tardiness } & \multicolumn{3}{|c|}{ Weekly Backorder Quantities } \\
\hline Grouping & Mean & Method & Grouping & Mean & Method \\
\hline A & 121,083 & $\mathrm{~A}-\mathrm{N}$ & A & 13,922 & A-N \\
\hline B & 81,984 & DA-N & $\mathrm{B}$ & 10,903 & DA-N \\
\hline $\mathrm{C}$ & 92,441 & $\mathrm{~N}-\mathrm{N}$ & $\mathrm{C}$ & 11,610 & $\mathrm{~N}-\mathrm{N}$ \\
\hline \multicolumn{3}{|c|}{ Number of Late Orders } & \multicolumn{3}{|c|}{ Percent of Orders Late } \\
\hline Grouping & Mean & Method & Grouping & Mean & Method \\
\hline A & 6,362 & $\mathrm{~A}-\mathrm{N}$ & A & 15.79 & A-N \\
\hline B & 4,637 & DA-N & B & 11.51 & DA-N \\
\hline $\mathrm{C}$ & 4,990 & $\mathrm{~N}-\mathrm{N}$ & $\mathrm{C}$ & 12.38 & $\mathrm{~N}-\mathrm{N}$ \\
\hline
\end{tabular}


Figure 2

Interaction of Forecasting Method and Safety Stock Setting: Number of Late Orders

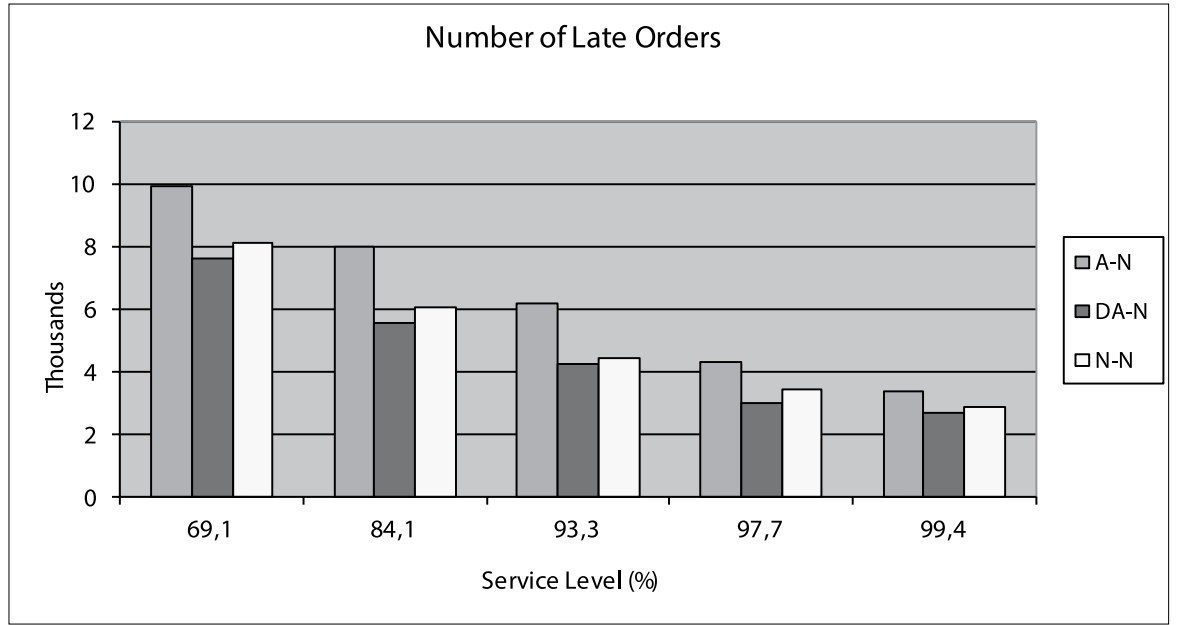

Figure 3

Interaction of Forecasting Method and Safety Stock Setting: Weighted Tardiness

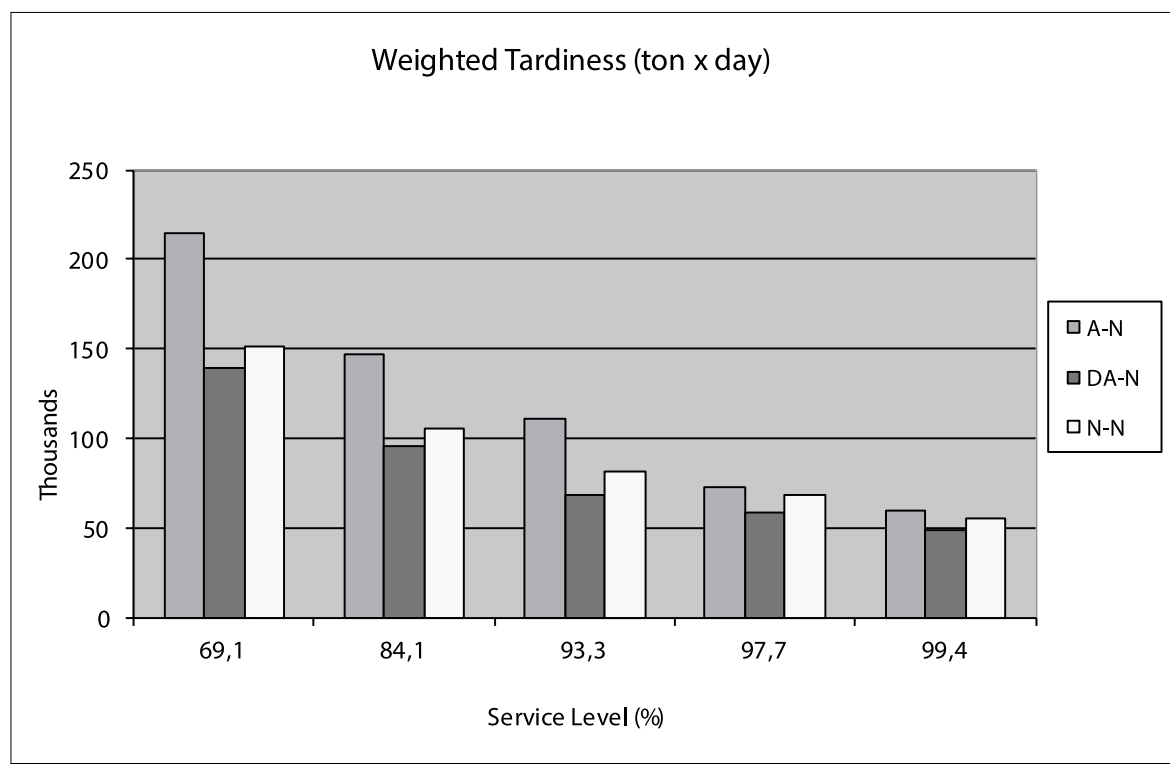


Figure 4

Interaction of Forecasting Method and Safety Stock Setting: Weekly Backorder Quantity

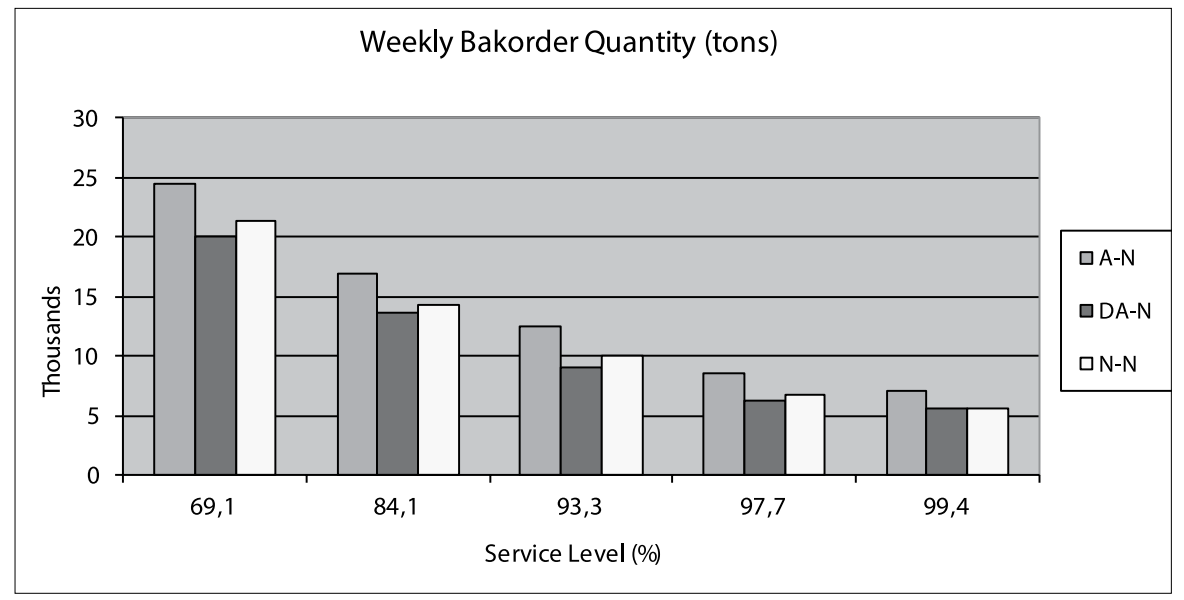

Figure 5

Interaction of Forecasting Method and Safety Stock Setting: Percent of Orders Late

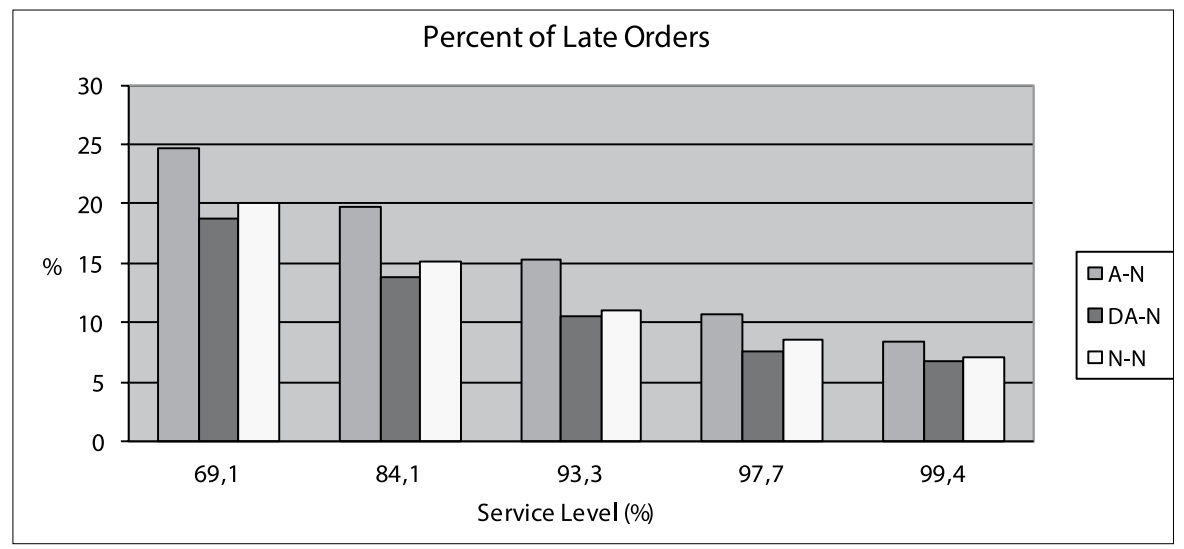

\section{ANOVA and Turkey's Means Test Results: Cost Measures}

The bar graphs in Figures 6-9 show the effects of the forecasting method and safety stock setting interaction on the shipment, production, inventory as well as the total supply chain cost measures. Tables 7-10 show ANOVA results for these four costs, respectively. Table 11 summarizes Turkey's means test results.

Shipment Costs: The main effects of the forecasting method used and the safety stock setting on shipment costs are statistically significant (see Table 7). In terms of the main effect of the forecasting method used, the lowest to highest shipment costs are returned by DA-N, N-N, and A-N methods at all safety stock settings. Moreover, all three methods are statistically significantly different based on Tukey's means test results (see Table 11). In terms of the main effect of the safety stock setting, the shipment costs decrease marginally as the safety stock setting is increased toward $84.1 \%$. Beyond that 
point, however, the shipment costs climb back-up considerably. This is due to the fact that increasing the component safety stocks will at first reduce emergency component shipments, but then increase the shipment costs associated with the replenishment of the safety stock itself. Figure 6 shows this pattern. On the other hand, the interaction effect between the safety stock level and the forecasting method used is not significant. (See Table 7 and Figure 6.)

Production Costs: ANOVA results indicate that the main and interaction effects of the forecasting method used and the safety stock setting are significant at $5 \%$ level (see Table 8 and Figure 7). In general, as the safety stock setting is increased to provide higher customer service, production costs increase slightly, possibly in response to the increased production needs to maintain the greater safety stock quantities. Of the three forecasting methods, the DA-N methods yield statistically significantly lower production costs than the N-N and A-N methods (see Table 8).

Inventory Carrying Costs: Inventory carrying costs for component inventory kept in the plants and inventory in transit are calculated during the simulation. Weekly inventory levels at the plants are recorded at the end of each week and used in the calculation of inventory carrying costs. As revealed by ANOVA, increasing the safety stock levels also resulted in considerably higher inventory carrying costs under all forecasting methods.

The effects of forecasting errors on inventory levels are extremely complicated. To illustrate this complexity, consider the effects of under-forecasting for a single plantcomponent, which can drag the inventory down to zero and create backorders. But backorders usually develop not just for that component, but often for others as well. What happens is that under-forecasting sets off a chain reaction due to capacity constraints. To cover backorders for a single component, capacity is borrowed from routine production schedules for other components, and they in turn can suffer shortages of stock at a later date. Backorders also can necessitate transshipments which results in an increase in the inventory levels in transit. On the other hand, over-forecasting for a single component means that capacity has been put to the wrong use, and excess stocks are created. What is surprising is that over-forecasting can also create backorders. During the time that limited capacity is devoted to building excess stocks, components competing for that capacity may suffer shortages of stock and incur backorders, and later cause emergency shipments as capacity becomes available. The damped trend exponential smoothing method generated fewer backorders overall than did the other forecasting methods and generated lower inventory carrying costs on the average. However, the differences in inventory carrying costs among the three forecasting methods are not significant (see Figure 8 and Table 11.)

Total Supply Chain Costs: ANOVA results in Table 10 show that the main effects of the forecasting method used and safety stock setting are significant at $0.01 \%$ level. Tukey's test results in Table 11 show that the three forecasting methods produced significantly different results. The DA-N method yields the lowest total cost, followed by the N-N, and A-N methods, in increasing order. 
Table 7

ANOVA Results for Shipment Costs

\begin{tabular}{llll}
\hline Shipment Cost & \multicolumn{4}{l}{$\mathrm{R}^{2}: 0.604$} & \\
\hline Source & $\mathrm{DF}$ & $\mathrm{F}$ & $\mathrm{Pr}$ \\
\hline Model & 14 & 33.613 & $<.0001$ \\
\hline Forecast_Method & 2 & 62.957 & $<.0001$ \\
\hline Safety_Stock & 4 & 84.707 & $<.0001$ \\
\hline Forecast_Method * Safety_Stock & 8 & .729 & .666 \\
\hline
\end{tabular}

Table 8

ANOVA Results for Production Costs

\begin{tabular}{l|lll}
\hline Production Cost & \multicolumn{4}{l}{ R $: 0.964$} & \\
\hline Source & DF & F & Pr \\
\hline Model & 14 & 577.995 & $<.0001$ \\
\hline Forecast_Method & 2 & 762.416 & $<.0001$ \\
\hline Safety_Stock & 4 & 1639.499 & $<.0001$ \\
\hline Forecast_Method * Safety_Stock & 8 & 1.137 & .0338 \\
\hline
\end{tabular}

Table 9

ANOVA Results for Inventory Carrying Costs

\begin{tabular}{lllll}
\hline Inventory Carrying Cost & \multicolumn{4}{l}{$\mathrm{R}^{2}: 0.988$} \\
\hline Source & $\mathrm{DF}$ & $\mathrm{F}$ & $\mathrm{Pr}$ \\
\hline Model & 14 & 1744.461 & $<.0001$ \\
\hline Forecast_Method & 2 & 2.626 & .074 \\
\hline Safety_Stock & 4 & 6065.465 & $<.0001$ \\
\hline Forecast_Method * Safety_Stock & 8 & 19.417 & $<.0001$ \\
\hline
\end{tabular}

Table 10

ANOVA Results for Total Supply Chain Costs

\begin{tabular}{llll}
\hline Total Cost & \multicolumn{4}{l}{$\mathrm{R}^{2}: 0.965$} & \\
\hline Source & $\mathrm{DF}$ & $\mathrm{F}$ & $\mathrm{Pr}$ \\
\hline Model & 14 & 592.495 & $<.0001$ \\
\hline Forecast_Method & 2 & 783.214 & $<.0001$ \\
\hline Safety_Stock & 4 & 1681.005 & $<.0001$ \\
\hline Forecast_Method * Safety_Stock & 8 & .56 & .81 \\
\hline
\end{tabular}


Table 11

Tukey's Means Test Results for the Customer Service Measures $(n=100)$

\begin{tabular}{|c|c|c|c|c|c|}
\hline \multicolumn{3}{|c|}{ Shipment Costs } & \multicolumn{3}{|c|}{ Production Costs } \\
\hline Grouping & Mean & Method & Grouping & Mean & Method \\
\hline A & $6,468,262$ & A-N & A & $111,022,893$ & $\mathrm{~A}-\mathrm{N}$ \\
\hline $\mathrm{B}$ & $6,152,332$ & DA-N & B & $109,542,063$ & DA-N \\
\hline $\mathrm{C}$ & $6,259,897$ & $\mathrm{~N}-\mathrm{N}$ & $\mathrm{C}$ & $109,823,207$ & $\mathrm{~N}-\mathrm{N}$ \\
\hline \multicolumn{3}{|c|}{ Inventory Carrying Costs } & \multicolumn{3}{|c|}{ Total Supply Chain Costs } \\
\hline Grouping & Mean & Method & Grouping & Mean & Method \\
\hline A & 709,791 & A-N & A & $118,200,946$ & $\mathrm{~A}-\mathrm{N}$ \\
\hline A & 709,790 & DA-N & $\mathrm{B}$ & $116,404,186$ & DA-N \\
\hline A & 712,538 & $\mathrm{~N}-\mathrm{N}$ & $\mathrm{C}$ & $116,795,644$ & $\mathrm{~N}-\mathrm{N}$ \\
\hline
\end{tabular}

Figure 6

Interaction of Forecasting Method and Safety Stock Setting: Shipment Costs

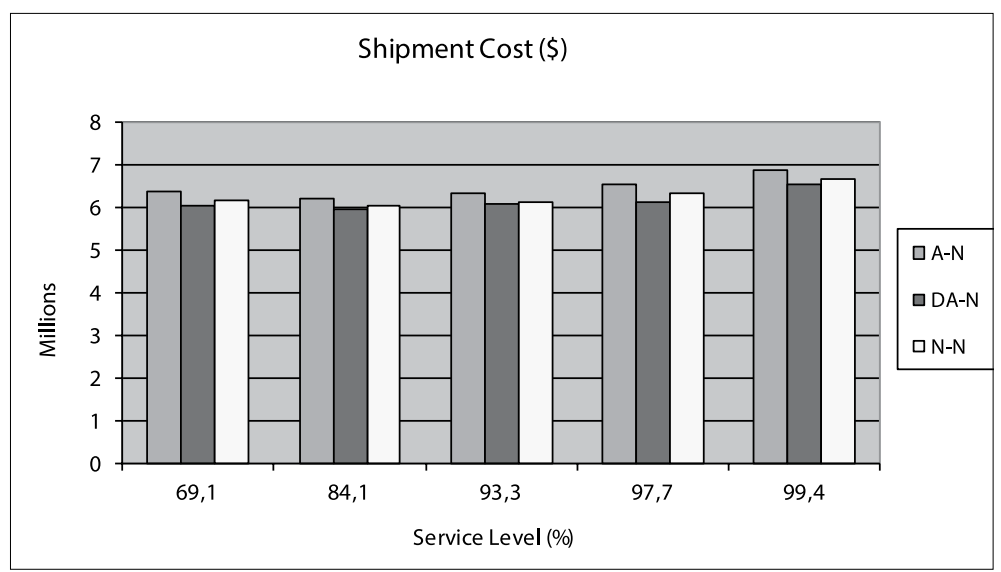


Figure 7

Interaction of Forecasting Method and Safety Stock Setting: Production Costs

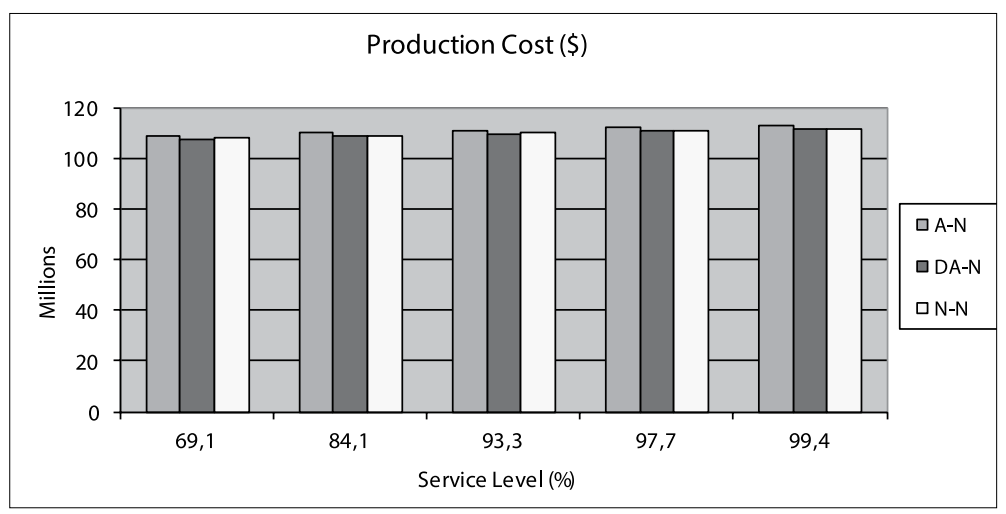

Figure 8

Interaction of Forecasting Method and Safety Stock Setting: Inventory Costs

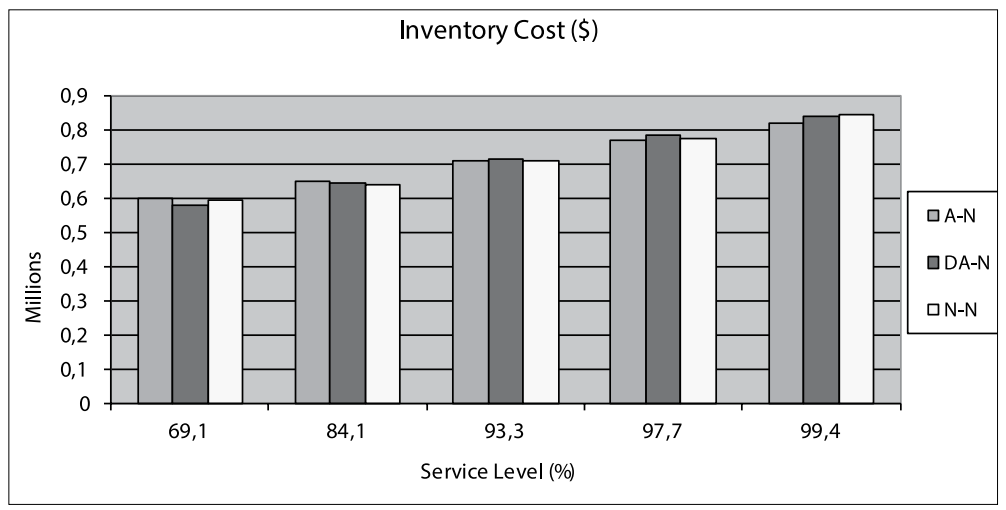

Figure 9

Interaction of Forecasting Method and Safety Stock Setting: Total Cost

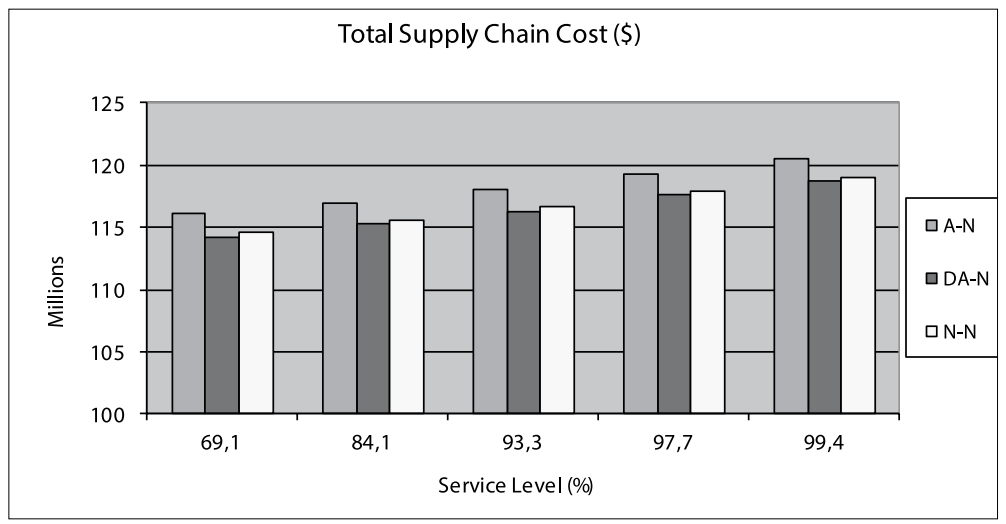




\section{Conclusions}

Although operational performance is the primary concern of most managers, most previous research related to forecasting for supply chains has avoided the question of how forecasting methods should be chosen, and has been concerned instead with examining the negative effects of demand uncertainty. As discussed in Acar et al. (2009), deterministic and often simplistic mathematical models are widely employed and are followed by multiple sensitivity analyses to judge the impact of demand uncertainty on decision making..

The objective of this study was to assess and compare the performance of some well-established demand forecasting methods - namely, simple exponential smoothing $(\mathrm{N}-\mathrm{N})$, exponential smoothing with additive trend (A-N), and exponential smoothing with damped additive trend (DA-N) methods - on the basis of operational performance in a global, specialty chemicals supply chain. The component demand forecasts are used to optimize component production and transportation plans. A simulation model then executes these plans in the presence of demand, lead-time and supply uncertainties. We found that the choice of the forecasting method affected both customer service and cost performance, and that the magnitude of the effect was strongly influenced by the safety stock level alternatives assumed for the components. In general, the higher the safety stock levels, the less prominent the difference among the three forecasting methods. In brief, the results underscore the importance of incorporating all relevant costs and customer service measures into the forecasting method selection and safety stock determination process, which is only possible with a thorough understanding of the supply chain dynamics.

Medium-term, one through six months ahead forecasts were used in planning. However, only the first month's production and shipment plans were implemented, updating the 6-month plans in rolling horizon fashion every month. Of the three forecasting methods we evaluated, DA-N was the most advantageous in terms of both cost and customer service measures, followed in descending order by N-N, and A-N respectively. This superiority of the DA-N method is consistent with earlier empirical reports of its ability to perform well especially in the long forecast horizons. This should prove to be an advantage for the DA-N method because, even though only the first month's production and shipment plans are implemented in rolling fashion, long-range forecasts of six months are used in planning.

Keep in mind that all components contribute forecast errors that interact with each other in allocating production capacity, and the system is dynamic with monthly updates. This means that forecast errors are sometimes reversed before the system has fully responded to previous backorders or excess stocks. Given this complexity, the best that can be done in explaining the performance of the damped trend model is to say that the method consistently generated fewer backorders and emergency shipments than did the other methods. 


\section{References}

Acar, Y., Kadıpaşaoğlu, S.N., and Day, J. (2009). "A General Approach for Incorporating Uncertainty in Optimal Decision Making: Iterative Use of MIP and Simulation in Solving Combinatorial Problems," Computers and Industrial Engineering, 56(1): 106-112

Acar, Y., Kadıpaşaoğlu, S., and Schipperijn, P. (2010). "A Decision Support Framework for Global Supply Chain Modeling: An Assessment of the Impact of Demand, Supply, and Lead-time Uncertainties on Performance," International Journal of Production Research, 48(11): 3245-3268.

Acar, Y. and Gardner, E.S. Jr. (2012). "Forecasting Method Selection in a Global Supply Chain," International Journal of Forecasting, 28(4): 842-848

Adshead, N.S. and Price, D.H.R. (1987). "Demand Forecasting and Cost Performance in a Model of a Real Manufacturing Unit." International Journal of Production Research, 25(9): 1251-1266.

Chen, F., Drezner, Z., Ryan, J K., and David, S-L. (2000). "Quantifying the Bullwhip Effect in a Simple Supply Chain: The Impact of Forecasting, Lead Times, and Information." Management Science, 46(3) 436-444.

Eaves, A.H.C. and Kingsman, B.G. (2004). "Forecasting for the Ordering and Stock-holding of Spare Par," Journal of the Operational Research Society, 55(4): 431-437.

Flores, B.E., Olson, D.L., and Pearce, S.L. (1993). "Use of Cost and Accuracy Measures in Forecasting Method Selection: A Physical Distribution Example," International Journal of Production Research, 31(1): 139-161.

Gardner, E.S. Jr. and McKenzie E. (1985). "Forecasting Trends in Time Series," Management Science, 31(10): 1237-1246.

Gardner, E.S. Jr. (1988). “A Simple Method of Computing Prediction Intervals for Time Series Forecasts," Management Science, 34(4): 541-546.

------, (1990). "Evaluating Forecast Performance in an Inventory Control System," Management Science, 36(4), 490-499.

------, (2006). "Exponential Smoothing: The State of the Art - Part II," International Journal of Forecasting, 22: 637-666

Holt, C.C. (2004). "Forecasting Seasonals and Trends by Exponentially Weighted Moving Averages," International Journal of Forecasting, 20: 5-10

Hyndman, R.J., Koehler, A.B., Snyder, R.D., and Grose, S. (2002). "A State Space Framework for Automatic Forecasting Using Exponential Smoothing Methods," International Journal of Forecasting, 18: 439-454.

Lee, H.L., and Billington, C. (1995) "The Evolution of Supply-Chain-Management Models and Practice at Hewlett-Packard," Interfaces, 25(5): 42-63.

Lee, H.L., Padmanabhan, V., and Whang, S. (1997). "Information Distortion in a Supply Chain: The Bullwhip Effect," Management Science, 43(4): 546-558.

Makridakis, S., Andersen, A., Carbone, R., Fildes, R., Hibon, M., Lewandowski, R., Newton, J., Parzen, E., and Winkler, R. (1982). "The Accuracy of Extrapolation (Time Series) Methods: Results of a Forecasting Competition,” Journal of Forecasting, 1(2): 111-153.

Makridakis, S., Wheelwright, S.C., and Hyndman, R.J. (1998). Forecasting: Methods and Applications (third edition), John Wiley and Sons. 
Makridakis, S. and Hibon, M. (2000). "The M3-Competition: Results, Conclusions and Implications," International Journal of Forecasting, 16(4): 451-476.

Pegels, C.C. (1969). "Exponential Forecasting: Some New Variations," Management Science, 15: 311-315.

Qi, X., Bard, J.F., and Yu, G. (2004). "Supply Chain Coordination with Demand Disruptions." Omega: The International Journal of Management Science, 32(4): 301-313.

Sanders, N.R. and Graman, G.A. (2009). "Quantifying Costs of Forecast Errors: A Case Study of the Warehouse Environment," Omega: The International Journal of Management Science, 37: 116-125.

Snyder, R.D., Koehler, A.B., and Ord, J.K. (2002). "Forecasting for Inventory Control with Exponential Smoothing." International Journal of Forecasting, 18: 5-18.

Syntetos, A.A., and Boylan, J.E. (2001). "On the Bias of Intermittent Demand Estimates," International Journal of Production Economics, 71(1): 457-466.

Syntetos, A.A., Keyes, M., and Babai, M.Z. (2009). "Demand Categorisation in a European Spare Parts Logistics Network,” International Journal of Operations and Production Management, 29(3): 292-316.

Syntetos, A.A., Nikoloupoulos, K., and Boylan, J.E. (2010). "Judging the Judges through

Accuracy-Implication Metrics: The Case of Inventory Forecasting," International Journal of Forecasting, 26(1): 134-143.

Taylor, J.W. (2003). "Exponential Smoothing with a Damped Multiplicative Trend," International Journal of Forecasting, 19(4): 715-726.

Tiacci, L. and Saetta, S. (2009). "An Approach to Evaluate the Impact of Interaction between

Demand Forecasting Method and Stock Control Policy on the Inventory System Performances," International Journal of Production Economics," 118: 63-71.

Tukey, J.W. (1949). “Comparing Individual Means in the Analysis of Variance,” Biometrics, 99-114.

Upton, D.M. (1994). "The Management of Manufacturing Flexibility.” California Management Review, 36(2): 72-90.

Vidal, C.J. and Goetschackx, M. (2000). "Modeling the Effect of Uncertainties on Global Logistics System," Journal of Business Logistics, 21: 95-120. 